AperTO - Archivio Istituzionale Open Access dell'Università di Torino

\title{
Multidisciplinary medical identification of a French king's head (Henry IV)
}

\section{This is the author's manuscript}

Original Citation:

\section{Availability:}

This version is available http://hdl.handle.net/2318/81995

since 2015-12-11T14:45:10Z

Published version:

DOI:10.1136/bmj.c6805

Terms of use:

Open Access

Anyone can freely access the full text of works made available as "Open Access". Works made available under a Creative Commons license can be used according to the terms and conditions of said license. Use of all other works requires consent of the right holder (author or publisher) if not exempted from copyright protection by the applicable law. 


\section{(5) \\ UNIVERSITÀ DEGLI STUDI DI TORINO}

This is an author version of the contribution published on:

Questa è la versione dell'autore dell'opera:

[BMJ 34, 2010; DOI: 10.1136/bmj.c6805]

The definitive version is available at:

La versione definitiva è disponibile alla URL:

[http://www.bmj.com/content/341/bmj.c6805] 


\section{Multidisciplinary medical identification of a French king's head (Henri IV)}

BMJ 2010; 341 doi: http://dx.doi.org/10.1136/bmj.c6805 (Published 15 December 2010) Cite this as: BMJ 2010;341:c6805

\section{This article has corrections. Please see:}

1. Philippe Charlier, forensic medical examiner and osteo-archaeologist $\underline{12}$,

2. Isabelle Huynh-Charlier, radiologist $\underline{3}$,

3. Joël Poupon, biological toxicologist $\underline{4}$,

4. Christine Keyser, specialist in forensic genetics $\underline{5}$,

5. Eloïse Lancelot, elemental toxicologist $\underline{6}$,

6. Dominique Favier, organic molecular analyst $\underline{7}$,

7. Jean-Noël Vignal, doctor in anthropology $\underline{8}$,

8. Philippe Sorel, arts historian $\underline{9}$,

9. Pierre F Chaillot, resident $\underline{1}$,

10. Rosa Boano, anthropologist $\underline{10}$,

11. Renato Grilletto, professor of anthropology $\underline{10}$,

12. Sylvaine Delacourte, perfumer11,

13. Jean-Michel Duriez, perfumer $\underline{12}$,

14. Yves Loublier, palynologist 13 ,

15. Paola Campos, specialist in paleogenetics 14 ,

16. Eske Willerslev, professor in paleogenetics 14 ,

17. M T P Gilbert, specialist in paleogenetics 14 ,

18. Leslie Eisenberg, forensic anthropologist $\underline{15}$,

19. Bertrand Ludes, professor of legal medicine $\underline{5}$,

20. Geoffroy Lorin de la Grandmaison, professor of legal medicine 1

\section{$\underline{\text { Author affiliations }}$}

1. Correspondence to: P Charlier ph_charlier@yahoo.fr

- Accepted 19 November 2010

Philippe Charlier and a multidisciplinary team explain how they confirmed an embalmed head to be that of the French king Henry IV using a combination of anthropological, paleopathological, radiological, forensic, and genetic techniques

The team examined the inside of the head with an endoscope. Here you can see the trachea, with the cartilage rings and vocal cords still preserved.

CT scanning enabled the team to image the skull, and from this build up a facial reconstruction to compare to portraits.

Since the desecration of the French kings' graves in the basilica of Saint-Denis by the revolutionaries in 1793, few remains of these mummified bodies have been preserved and identified. After a multidisciplinary analysis, we confirmed that an embalmed head reputed to be 
that of the French king Henri IV and conserved in successive private collections did indeed belong to that monarch.

\section{Death of "the green gallant"}

Henri IV was probably the most popular French king. He was known as "the good King Henry" or, because of his attractiveness to women, "the green gallant." Despite being admired by his people, he was assassinated in Paris at the age of 57 years on 14 May 1610 by François Ravaillac, a fanatical Catholic.

\section{Identifying the remains of the French king}

The human head had a light brown colour, open mouth, and partially closed eyes (fig $1 \underline{\Downarrow}$ ). The preservation was excellent, with all soft tissues and internal organs well conserved. Two features often seen in portraits of the monarch (fig $2 \underline{\Downarrow}$ ) were present: a dark mushroom-like lesion, $11 \mathrm{~mm}$ in length, just above the right nostril (fig $3 \mathrm{~A} \underline{\Downarrow}$ ), $\underline{1}$ and a $4.5 \mathrm{~mm}$ central hole in the right ear lobe with a patina that was indicative of long term use of an earring (fig 3B). We know that Henri IV wore an earring in his right earlobe, as did others from the Valois court. 2 A $5 \mathrm{~mm}$ healed bone lesion was present on the upper left maxilla (fig 3C), which corresponds to the trauma (stab wound) inflicted by Jean Châtel during a murder attempt on 27 December 1594.2 Many head hairs and remnants of a moustache and beard were present; they were red and white in colour, with a maximum length of 7 $\mathrm{mm}, 24 \mathrm{~mm}$, and $60 \mathrm{~mm}$, respectively (fig 3E and F). This fits with the known characteristics of the King's hair at the time of his death. 2 The head also showed evidence of baldness - no hair was present on the pate. Dental health was poor, with considerable antemortem tooth loss; this corresponds with testimonies from contemporaneous witnesses about the king. 2 Lastly, three postmortem inferior cervical cutting wounds were visible, corresponding to the separation of the head from the body by a revolutionary in 1793 , in the context of deliberate mutilation. $\underline{3}$
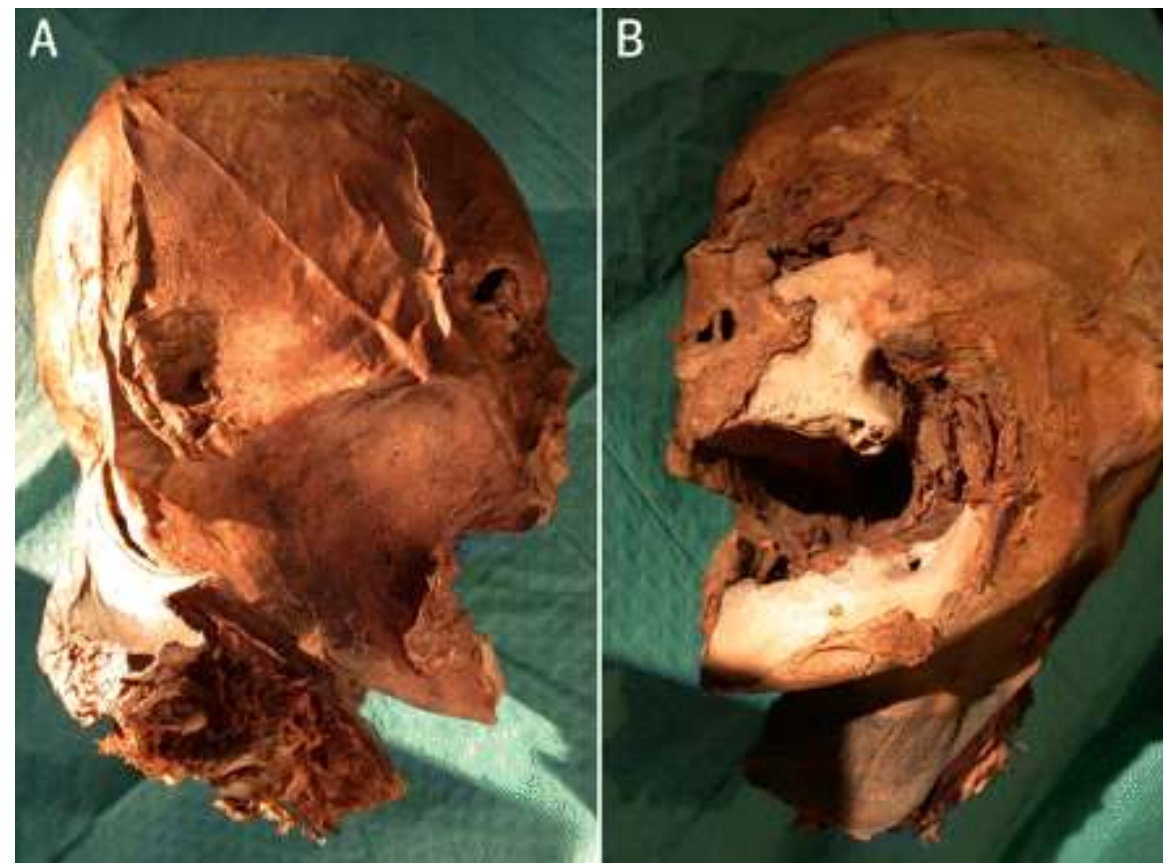

Fig 1 Left lateral (A) and right lateral (B) view of the mummified head

- Download figure 
- Open in new tab

- Download powerpoint

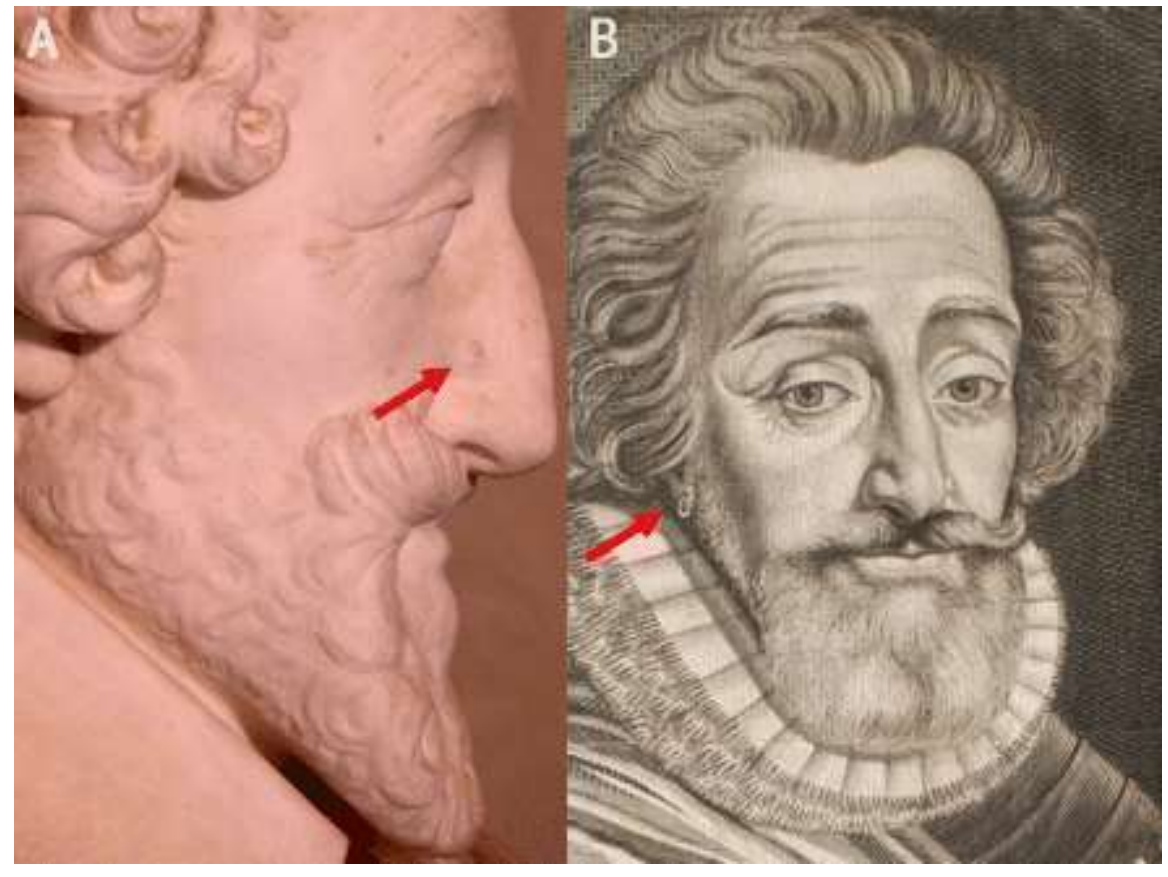

Fig 2 A: Left sided view of the statue of King Henri IV at Pau Castle showing the nasal skin lesion. $\mathrm{B}$ : French engraving by Ganières showing the king wearing an earring in the right ear lobe

- Download figure

- Open in new tab

- Download powerpoint 

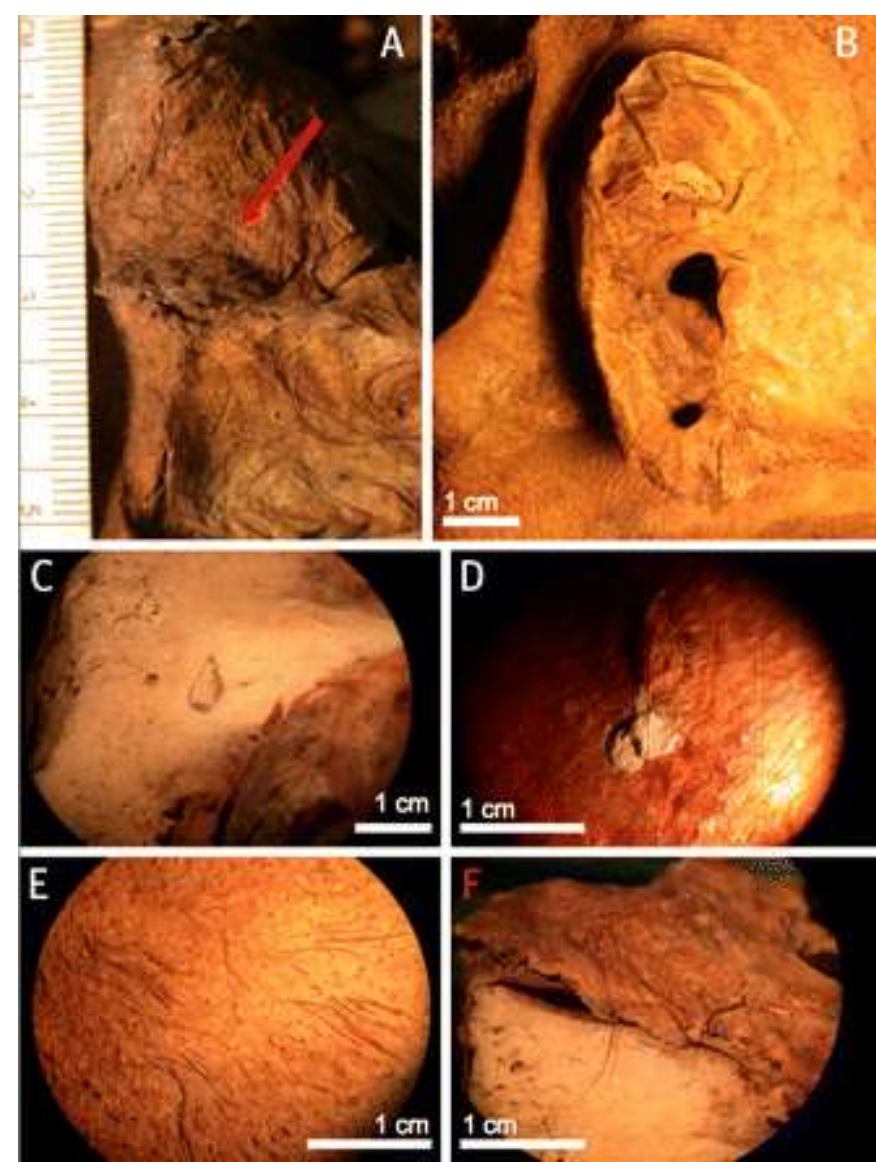

Fig 3 Details of the different facial characteristics: (A) nasal naevus (arrow), (B) pierced right ear lobe, $(\mathrm{C})$ post-trauma maxillary bone lesion, (D) grey scalp deposit, (E) red moustache, and (F) red hairs

- Download figure

- Open in new tab

- Download powerpoint

\section{Other evidence in favour of the identification}

Radiocarbon dating with 2-sigma calibration yielded a date of between 1450 and 1650, which nicely bracketing the year of Henri IV's death (1610). 2

We could not recover uncontaminated mitochondrial DNA sequences from the head samples, so no comparison was possible with other relics from the king and his descendants.

Analysis of various grey deposits (fig 3D) on the head showed an elemental and organic composition corresponding to successive mouldings of the head. We know that three mouldings were carried out on Henri IV's head: firstly on the fresh head in 1610, 2 then on the mummified head in 1793 just after the desecration, $\underline{3}$ and lastly by a previous owner (Bourdais) of the head at the beginning of the 20th century.

A digital facial reconstruction of the skull was fully consistent with all known representations of Henri IV and the plaster mould of his face made just after his death, which is conserved in the Sainte-Genevieve Library, Paris. The reconstructed head had an angular shape, with a high forehead, a large nose, and a prominent square chin (fig $4 \underline{\Downarrow}$ ). $\underline{2}$ Superimposition of the skull on the 
plaster mould of his face and the statue at Pau Castle showed complete similarity with regard to all these anatomical features (fig $5 \underline{\Downarrow}$ ).
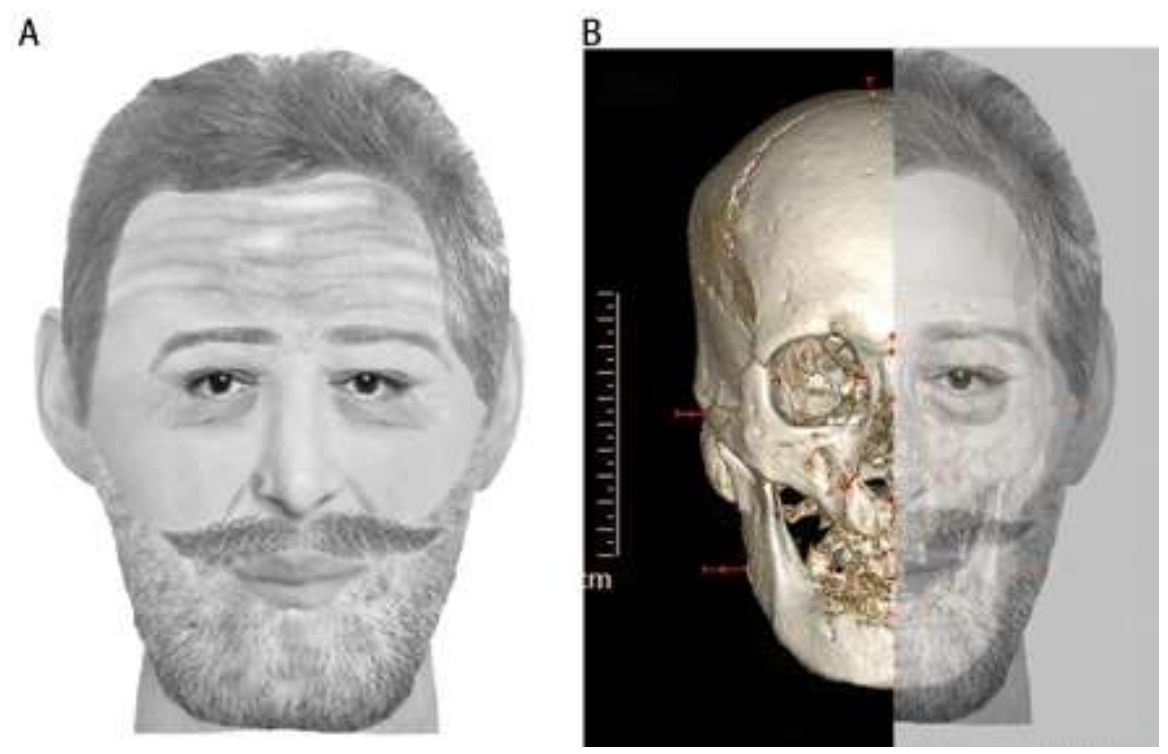

Fig 4 Digital reconstruction of (A) the complete face and (B) the left side of the face using data from three dimensional computed tomography scans of the skull and the particular characteristics of the mummified head

- Download figure

- Open in new tab

- Download powerpoint
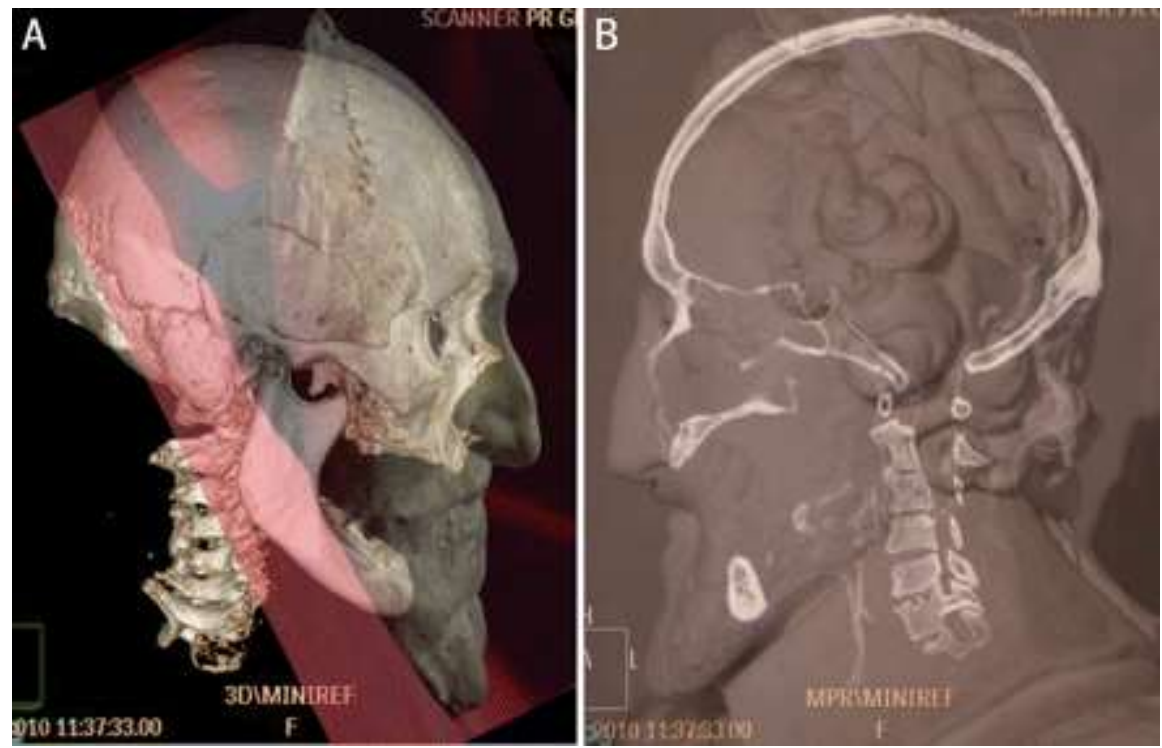

Fig 5 A: Digital superimposition of (A) the computed tomography scan (right sided view of the skull) on to the face mould made just after Henry IV's death. B: Digital superimposition of the computed tomography scan (sagittal section of the skull) on to the left sided view of the statue of the king at Pau Castle

- Download figure

- Open in new tab 


\section{A very particular embalming method}

The autopsy report of King Henri IV, published in the complete works of the surgeon Guillemeau (1549-1613), $\underline{4}$ showed that the brain was not examined. Such an examination was not systematically performed when the cause of death was known (which for Henri IV was two knife wounds made in the thorax by Ravaillac). 2 Another practitioner, Pigray (1532-1613), was in charge of the embalming process, $\underline{5}$ and he took into account the king's wish to be embalmed "in the style of the Italians." This form of embalming minimises the mutilating aspect of the embalming procedure by not opening the skull - the brain and all internal structures remain in the skull (no vault sawing, no evacuating trepanation, no ethmoidal perforation). Computed tomography of the head confirmed that no sign of skull base or vault trauma (except for the old maxilla lesion), sawing, or opening of the cerebral cavity was present.

A circumferential band of black pigment was seen on the skin at the base of the neck. Using Raman spectroscopy, it was identified as ivory black, a variety of amorphous carbon. This charcoal, obtained by anaerobic calcination of animal bones, corresponds to that deposited by the surgeon Pigray on the surface of the cadaver to absorb decomposition fluids and putrefactive gases $\underline{5}$; the precise upper limit of the cervical deposit may be explained by the head being protected by strips of cloth so that it was not blackened during the process.

We found many unidentifiable vegetal deposits in the mouth, which were, among other things, used to mask unpleasant odours that emanated from the oral cavity. $\underline{6}$ Mercury was sometimes used when the skull was left intact. It was usually deposited as cinnabar salts within the nostrils, which were tightly packed with segments of textile. $\underline{6}$ In this case, no trace of mercury was found in samples from the nostrils or the nasal cavity.

\section{Pathological background}

Computed tomography also showed partially conserved dura mater and dried brain parenchyma, with no identifiable anomalies. 7 Mummified vascular and nervous structures were seen in both orbital cavities, and the right orbital cavity contained a dense biconvex $7 \mathrm{~mm}$ disc. This disc corresponds to the eye lens, the high density (137 Hounsfield units) of which indicates the presence of a cataract. We also identified diffuse and moderate marginal spondylarthrosis in all cervical vertebrae.

\section{Conclusion}

Now positively identified according to the most rigorous arguments of any forensic anthropology examination, the French king's head will be reinterred in the royal basilica of Saint-Denis after a solemn funeral ceremony. Similar methods could be used to identify all the other kings' and queens' skeletons lying in the mass grave of the basilica, so that they can be returned to their original tombs.

\section{Notes}

Cite this as: $B M J$ 2010;341:c6805 


\title{
Related links
}

\author{
bmj.com/archive
}

- Christmas 2009: A gold elixir of youth in the 16th century French court (2009;339:b5311)

\section{Footnotes}

- Acknowledgments: All authors thank S Gabet (who rediscovered the head) and P Belet for historical investigations; J Bellanger (previous owner of the head); the conservators at Pontoise and Chateauroux et Pau; MH de La Mure (curator at the Sainte-Genevieve Library, Paris); MV Clin-Meyer (curator of the Museum of History of Medicine, Paris); Prince Louis-Alphonse de Bourbon and his secretary, X Bureau; Prince Michael of Greece; the French National Academy of Medicine (Paris); R Teyssou, who provided the endoscope; $\mathrm{P}$ Berche (Paris 5 University); A Jobet (IFF); and the $B M J$ reviewers (I Sosa and U Aasebo).

- Funding: No particular funding was used for this study.

- Competing interest declaration: All authors have completed the Unified Competing Interest form at www.icmje.org/coi_disclosure.pdf (available on request from the corresponding author) and declare: no support from any organisation for the submitted work; no relationships with any organisation that might have an interest in the submitted work in the past three years; no other relationships or activities that could appear to have influenced the submitted work.

- Contributors: PC conceived and headed the project, did the anthropological and paleopathological analyses, and the microscopic and endoscopic examinations. IHC did the radiological examinations and three dimensional computed tomography reconstructions. JP and LE did the elemental analyses. DF did the molecular organic analyses. JNV did the three dimensional facial reconstructions. PS provided data about historical face moulding. PFC did cranial measurements from computed tomography reconstructions. RG and RB provided comparative data about the Italian embalming process. SD and JMD performed professional olfaction. YL carried out botanical (pollen) observation from oral deposits. PFC, EW, MTPG, CK, and BL did ancient DNA extractions and analyses. PC wrote most of the manuscript, with critical input from LE, JP, GLDLG, and the remaining authors. CK is guarantor?]

- Provenance and peer review: Not commissioned; externally peer reviewed.

\section{References}

1.

Lever DE, ed. Histopathology of the skin. 10th ed. Lippincott Williams and Wilkins, 2008.

2.

Babelon JP. Henri IV. Fayard, 2009.

3. $\Perp$

De Lamartine A. Histoire des Girondins. Armand Le Chevalier, 1865. 


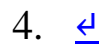

Guillemeau J. Oeuvres de chirurgie. Re-edition. Jean Viret, 1649.

5.

Pigray P. Epitome des préceptes de médecine et de chirurgie. Jean Berthelin, 1625:398-400.

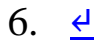

Charlier P. Evolution of embalming methodology in medieval and modern France (Agnès Sorel, the Duc de Berry, Louis the XIth, Charlotte de Savoie). Med Secoli2006;18:777-97.

TROVA@UnitoMedline

7. $\Perp$

Rühli FJ, Chhem RK, Böni T. Diagnostic paleoradiology of mummified tissue: interpretation and pitfalls. Can Assoc Radiol J2004;55:218-27.

TROVA@UnitoMedlineWeb of Science 